\title{
TAMAN VERTIKAL DI MATRAMAN
}

\author{
Octaviani Morgalita ${ }^{1)}$, Agustinus Sutanto $^{21}$
}

\author{
1) Program Studi S1 Arsitektur, Fakultas Teknik, Universitas Tarumanagara, archviant@gmail.com \\ 2) Program Studi S1 Arsitektur, Fakultas Teknik, Universitas Tarumanagara, afirawiniera@gmail.com
}

\begin{abstract}
Abstrak
Aktivitas transportasi dan mobilitas terus bertambah seiring dengan meningkatnya kesibukan dan pertumbuhan penduduk di kota Jakarta. Kota Jakarta merupakan kota metropolitan dengan jumlah kendaraan dan polusi udara yang tinggi, sehingga permasalahan utama yang timbul adalah penurunan degradasi kualitas lingkungan akibat pencemaran udara. Selain kualitas udara yang buruk juga berdampak pada kualitas fisik dan psikis penduduk yaitu berdampak pada gangguan paru - paru dan chronic stress. Maka dibutuhkannya sebuah ruang antara yang menjadi penetralisir dengan tujuan menyeimbangkan pola pikir dan kesehatan jasmani bagi manusia. Hal tersebut direalisasikan dengan dibuatnya bangunan "Matraman Vertical Park", dengan luas \pm 5.000 $\mathrm{m}^{2}$ yang memberikan wadah bagi manusia untuk "Stop" dan "Think", serta memberikan reaksi positif terhadap lingkungan sekitar. Lokasi bangunan berada di perbatasan antara Jakarta Pusat dan Jakarta Timur yang terletak di persimpangan Jalan Salemba Raya dan Jalan Pramuka Raya. Matraman Vertical Park merupakan ruang publik dan sosial berintegrasi dengan botanical garden yang menjawab dan memperbaiki isu penuruan kualitas lingkungan di kota Jakarta. Matraman Vertical Park menggunakan konsep Third Place yang menyediakan ruang bagi manusia untuk bersosialisasi dan memberikan penghiburan yang berkontribusi positif terhadap lingkungan perkotaan. Di dalam bangunan ini terdapat program yang cenderung ditujukan untuk public dan perkembangan bagi manusia maupun lingkungan, dengan konsep morphosis environment pada tata ruang yang menghadirkan interaction space bagi pengunjung kepada lingkungan sekitar.
\end{abstract}

Kata kunci: kota; lingkungan; polusi udara; taman

\begin{abstract}
With the rising of number of population and its business, transportation and mobility also rises. Jakarta has the highest number of vehicles and the most polluted metropolitan, as the main problem for Jakarta is the degradation of the environment quality caused by air pollution. Beside poor air quality also affects the physical quality and the population's psychic which are lung problems, and chronic stress. So, an in-between space is needed as a neutralizer with the purpose of balancing the thinking patters and human health. This neutralizer could be achieved with Matraman Vertical Park. With a total area of about 5.000 $\mathrm{m}^{2}$, this place gives humans to "Stop" and "Think" and react positively about the surrounding environment. The site is located between the borders of Jakarta Pusat and Jakarta Timur, specifically, at the intersection of JI. Salemba Raya and JI. Pramuka Raya. Matraman Vertical Park is an botanical-garden-integrated public and social space which reacts to the degradation of environment quality in Jakarta. Matraman Vertical Park applies the concept of Third Place which gives human the space to socialize and provide an entertainment that contribute positively to the city environment. The program of this building is open to public and with a purpose for the development of human and the environment. An Interaction space is presented with the concept of morphosis environment to the building's spaction for visitors.
\end{abstract}

Keywords: air pollution; environment; park 


\section{PENDAHULUAN}

Saat ini berbagai kota di Indonesia tengah mengalami berbagai permasalahan yang kompleks akibat berbagai aktivitas masyarakat kota yang berdampak langsung terhadap lingkungan. Permasalahan utama perkotaan saat ini dikarenakan perkembangan pembangunan yang semakin pesat sehingga terjadi penurunan degradasi kualitas lingkungan akibat pencemaran udara. Kota Jakarta merupakan kota metropolitan dimana setiap harinya terjadi peningkatan penggunaan jumlah kendaraan bermotor yang melintas sehingga mengakibatkan timbulnya polusi udara / gas-gas berbahaya, hal ini juga akan sangat mendukung terjadinya pemanasan global.

Menurut data Biro Pusat Statistik tahun 1999 di DKI Jakarta menunjukkan bahwa kendaraan bermotor merupakan pelepas polutan terbesar. Kontribusi polutan yang dilepaskan oleh kendaraan bermotor di DKI Jakarta sebesar $6.90 \%$ debu, $78.32 \% \mathrm{SO}_{2}, 29.18 \%$ Nox, $62.62 \%$ Hidrokarbon, $85.78 \% \mathrm{CO}$ clan $3.90 \% \mathrm{CO}_{2}$. Hingga saat ini lebih dari $70 \%$ pencemaran udara diakibatkan oleh emisi kendaraan bermotor (Arifin, 2009).

Aktivitas transportasi di jalan raya yang terus meningkat dari tahun ke tahun disebabkan oleh peningkatan pertumbuhan penduduk, peningkatan pendapatan dan daya tarik Kota Jakarta yang pesat. Jumlah kendaraan yang terus meningkat, dapat menimbulkan permasalahan yang serius yakni kemacetan, meningkatnya konsumsi bahan bakar dan semakin parahnya tingkat pencemaran udara akibat emisi gas buang yang dihasilkan (Soedomo, 2001). Berdasarkan data dari Badan Pusat Statistik (BPS) Indonesia, jumlah mobil penumpang pada tahun 2013 sebanyak 11.484.514 unit. Jakarta pun dinyatakan sebagai kota dengan polusi udara paling buruk didunia dan memasuki kategori tidak sehat.

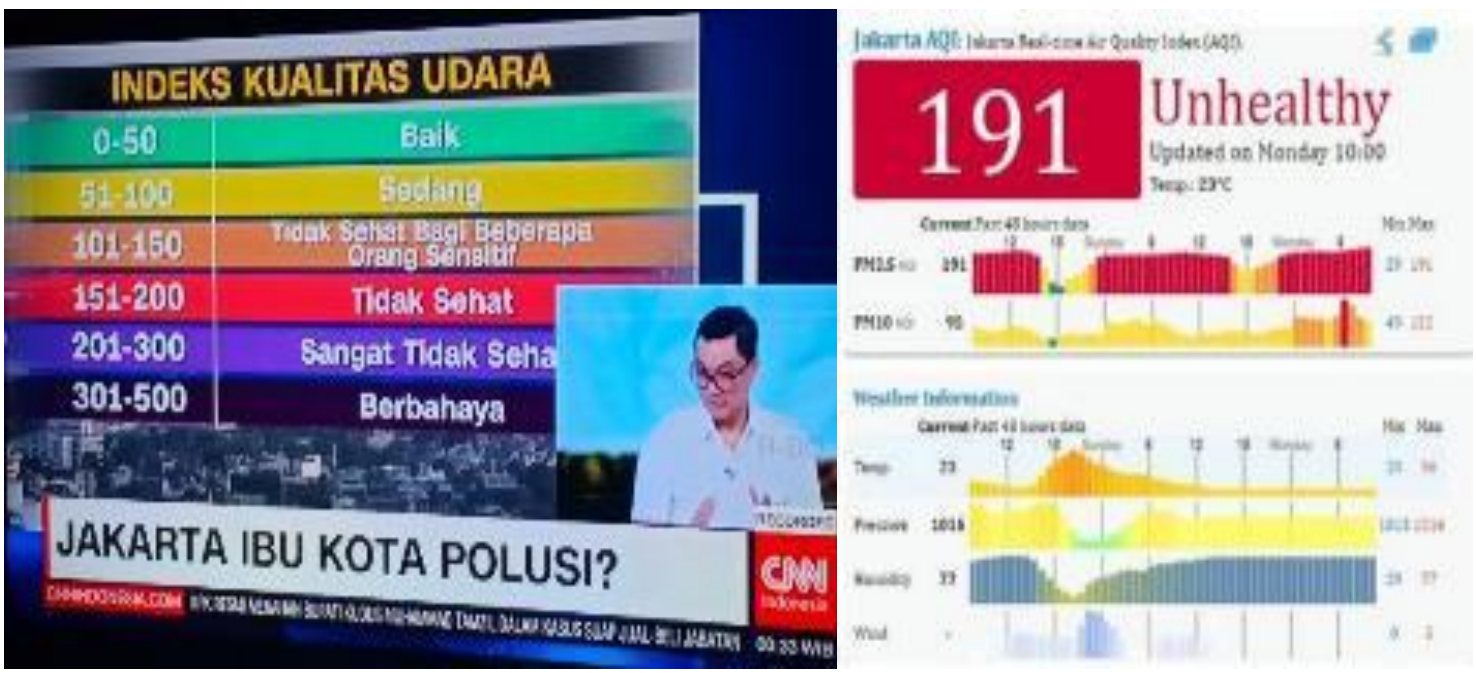

Gambar 1. Indeks Kualitas Udara di Jakarta

Sumber: AirVisual, 2019

Bertambahnya jumlah kendaraan bermotor ini akan berdampak pada segala aspek kehidupan. Rutinitas kehidupan manusia di tengah ruang hiruk pikuk kota metropolis yang kompleks seperti pada Kota Jakarta yang dipenuhi oleh polusi tidak menutut kemungkinan hidup manusianya bahagia, disinilah mental dan psikis manusia dapat terganggu dimana manusia akan merasa tertekan dan frustasi. Hal itu akan menyebabkan chronic stress dalam diri manusia. Gas karbon monoksida (CO), gas hidro karbon $(\mathrm{HC})$, dan $\mathrm{No}_{2}$ merupakan parameter pencemaran udara yang sangat perlu diperhatikan karena kedua gas tersebut adalah polutan yang sangat berbahaya dari kendaraan bermotor tentunya akan mengganggu kesehatan manusia khususnya mengakibatkan gangguan paru-paru. Menurut Laporan World Air Quality Report 2018 itu menyebut bahwa polusi udara ini diperkirakan menelan korban sekitar 7 juta jiwa diseluruh dunia setiap tahunnya. 


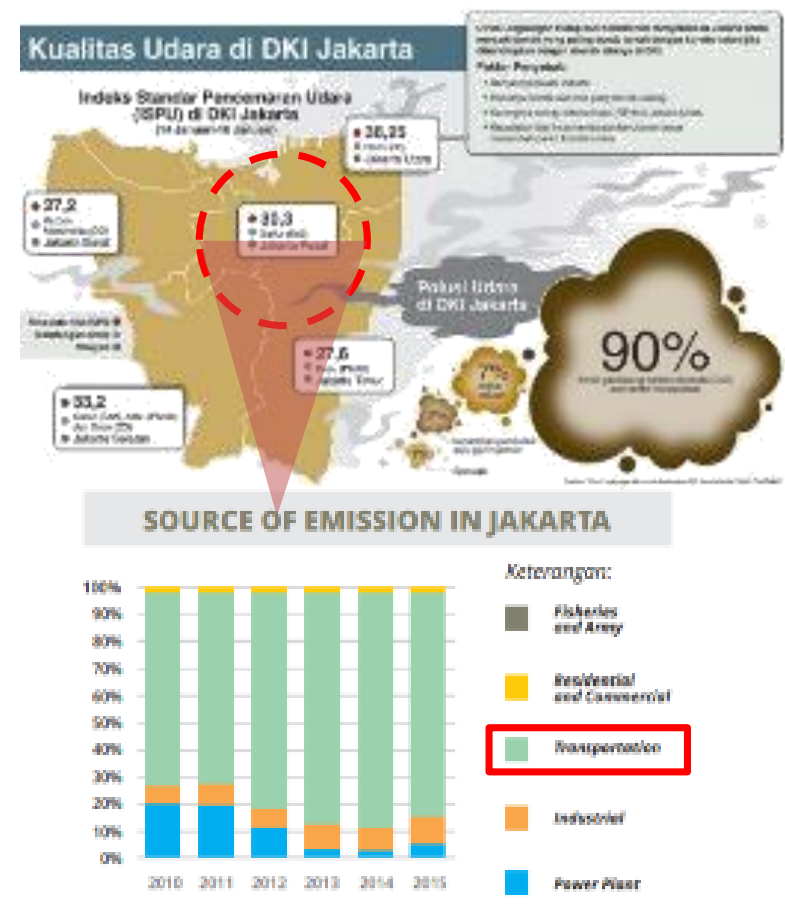

Gambar 2. Persentase Kualitas Udara di Jakarta Pusat Sumber: AirVisual, 2019

Oleh karena itu dibutuhkan ruang antara untuk menjadi penetralisir dengan tujuan menyeimbangkan pola pikir dan healing. Di dalam ruang tersebut, manusia metropolis masuk ke dalam sebuah implus dan regulasi diri serta peran dari panca indra, manusia membiarkan aktivitas healing bekerja dari dalam diri. Didalam bangunan ini, manusia akan melakukan "STOP" and "THINK" dimana manusia dapat memberikan reaksi positif terhadap lingkungan sekitar sebagai bentuk pengembangan diri. Ada 2 hal yang dapat menjadi penetralisir pola pikir yaitu ibadah / religious dan meditasi / alam.

\section{'STOP AND THINK'}

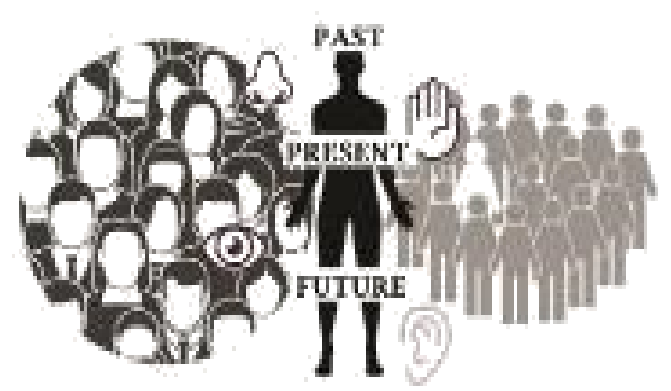

\section{SPIRIT}

Far. Haw was:

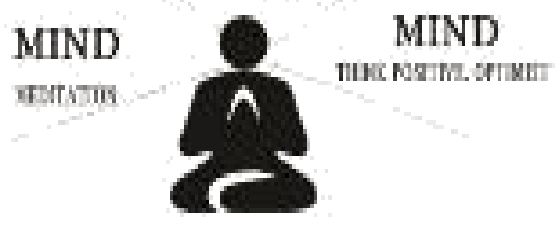

BODY

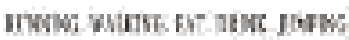

Gambar 3. Gambar Stop and Think

Sumber: Penulis, 2019

Tujuan perencanaan dan perancangan ini adalah untuk menghasilkan desain dengan fasilitas wisata, edukasi, dan penelitian serta memberikan akses masyarakat terhadap kawasan hijau sebagai wadah untuk meningkatkan kepedulian masyarakat dalam rangka menghargai dan memelihara lingkungannya. Selain itu alam juga membawa dampak baik bagi kesehatan manusia yaitu alam dapat menjadi paru - paru dan jantung kota yang dapat dimanfaatkan secara maksimal. 


\section{KAJIAN LITERATUR}

Ruang publik menjadi suatu ruang yang bebas untuk dimasuki dan diintervensi oleh siapapun yang dapat "menguasai" tempat ini. Ruang publik juga dapat diartikan sebagai suatu ruang yang bisa dipakai oleh siapa aja dan diperuntukan untuk siapa saja. Secara garis besar hal ini disebabkan oleh perbedaan latar belakang yang dimiliki oleh setiap manusia. Munculnya teori "third place" yang dinyatakan oleh Prof. Ray Oldenburg dikarenakan isu kebutuhan dari masyarakat akan suatu komunitas sosial dimana manusia bisa bebas dan bisa melupakan sejenak rutinitas harian yang biasa mereka lakukan. Ditempat itu semua manusia dianggap sama dan memiliki haknya yang sama.

\section{Arsitektur Urban}

Melalui buku Public Places Urban Spaces, Carmona (2003) menyatakan bahwa karakter dari suatu lingkungan urban tidak hanya dilihat dari kualitas ruang yang dirasakan, tetapi juga dari warna, tekstur, ataupun detail dari suatu permukaan. Ruang yang tergambar bisa terlihat tidak bersahabat jika permukaan pada ruang tersebut tidak menunjukan suatu detail yang jelas atau tidak mengikuti skala manusia. Hal lain yang bisa jadi penentu karakter suatu ruang adalah aktifitas yang terjadi baik disekitar maupun di dalam ruang.

Menurut Paul Zucker (1959) membicarakan tentang bagaimana suatu square harus mempresentasikan suatu organisasi ruang yang baik. Ruang terbuka dapat berupa lahan terbuka yang dapat digunakan oleh publik maupun kegunaan pribadi. Ruang tersebut dapat berupa ruang terbuka yang bersifat aktif maupun pasif. Ruang terbuka yang bersifat aktif merupakan space yang dapat digunakan untuk melakukan berbagai aktivitas, misalkan taman dan lapangan olahraga. Sedangkan ruang terbuka yang bersifat pasif, merupakan ruang terbuka yang hanya dapat dirasakan keberadaanya tanpa dapat dilakukan aktivitas didalamnya. Contoh ruang terbuka yang bersifat pasif adalah lahan yang berfungsi sebagai lahan preservasi dan konservasi ekologi, maupun lahan pertanian. Ruang terbuka tidak hanya mencakup lahan yang terdapat di tanah, melainkan juga dapat berupa lahan yang berada di permukaan air. la mengemukakan tipologi bentuk ruang terbuka, dapat dikategorikan menjadi 5 jenis, diantaranya ruang terbuka yang berbentuk closed square, nuclear square, dominated square, grouped square, \& common building.

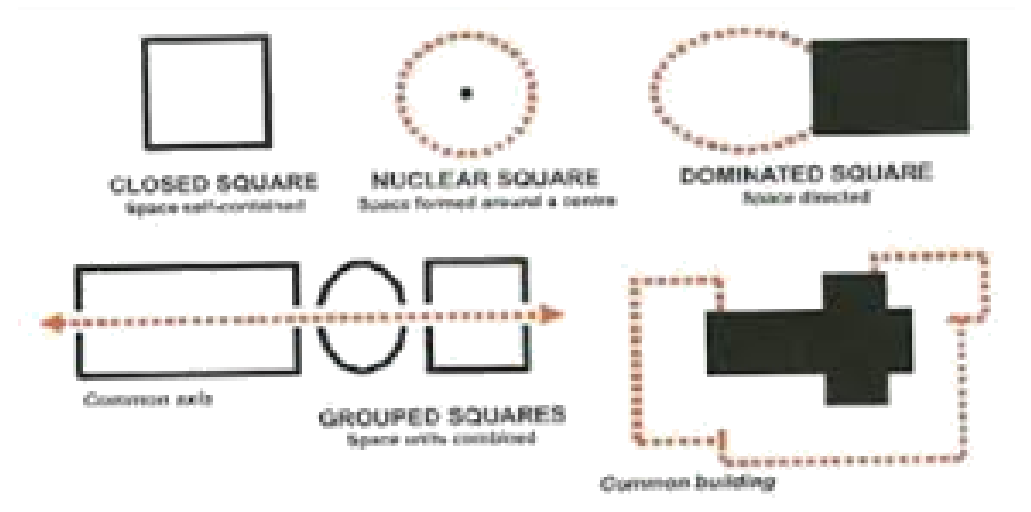

Gambar 4. Tipe Open Space berdasarkan bentuk Sumber: Zucker, 1959

\section{Ruang Sosial / Ruang Publik}

Di dalam square tersebut, dapat kita temukan berbagai ruang-ruang yang terbentuk, termasuk ruang sosial. Ruang sosial berisi berbagai elemen-elemen pembentuk, salah satunya adalah manusia. Manusia sendiri diciptakan sebagai makhluk sosial. Dalam pengertiannya, bahwa manusia itu tidak dapat hidup sendiri, mereka membutuhkan orang lain untuk dapat membantu dalam melanjutkan kehidupan atau menolong dalam memenuhi kebutuhan jasmani maupun rohani mereka. Menurut Marx and Engels, manusia sebagai makhluk sosial dikatakan 
memiliki kemampuan untuk menentukan hidup maupun dunianya sendiri. Dengan kata lain sebagai makhluk sosial manusia dapat memilih atau bergaul dengan individu atau kelompok manusia lainnya yang memang dapat membantu mereka dalam memenuhi keinginan atau kebutuhan manusia tersebut.

Bumi ini diciptakan dengan berbagai unsur alam yang juga berinteraksi dengan kehidupan manusia. Sebelum manusia menguasai alam itu sendiri, bumi ini sudah ada sebagaimana mestinya. Alam yang dikuasai oleh manusia akan berubah sesuai dengan kebutuhan atau hanya berdasarkan keinginan manusia semata. Ruang sosial yang nantinya akan menampung kegiatan sosial manusia merupakan bentukan hasil perbuatan manusia di dalamnya. Alam menyediakan sumbernya, sedangkan manusia memakainya untuk memenuhi kebutuhannya. Pada prinsipnya alamlah yang memiliki peran pertama kemudian diikuti oleh manusia yang menguasai alam tersebut lalu yang terakhir adalah pengetahuan atau teknologi yang dimiliki manusia dalam menguasai alam tersebut.

Menurut Bruno Zevi (1974) menyatakan bahwa pada awalnya ruang itu sebenarnya kosong yang kemudian diisi dengan intervensi dari "pihak luar". Menurutnya, geometri ruang yang terbentuk karena dibuat oleh sikap dan perilaku dari manusia yang menempatinya. Hal ini menyatakan bahwa setiap ruang arsitektur yang terbentuk baik didalam maupun di luar ruang itu sendiri merupakan tempat dimana kegiatan sosial itu terjadi.

Menurut Rustam Hakim (1987) mengatakan bahwa, ruang publik pada dasarnya merupakan satuan wadah yang dapat menampung aktivitas tertentu dari masyarakatnya, baik secara individu maupun secara kelompok, dimana bentuk ruang publik ini sangat tergantung pada pola dan susunan massa bangunan. Menurut sifatnya, ruang publik terbagi menjadi (a) ruang publik tertutup yaitu ruang publik yang terdapat di dalam suatu bangunan, (b) ruang publik terbuka yaitu ruang publik yang berada di luar bangunan yang sering juga disebut ruang terbuka (open space).

Menurut Purwanto (2007) berpendapat bahwa ruang publik merupakan sebuah setting yang dipengaruhi oleh tiga unsur selain unsur fisiknya yaitu manusia sebagai pelaku, kegiatan dan pikiran manusia.

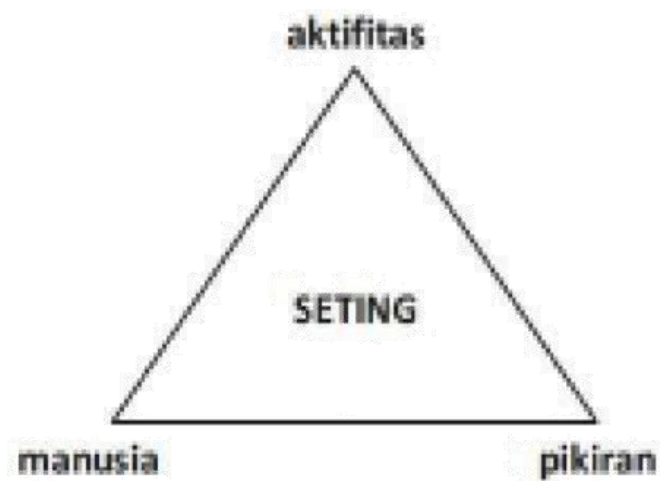

Gambar 5. Diagram keterkaitan pelaku, kegiatan, dan pikiran dalam seting Sumber: Purwanto, 2007

\section{Ruang Publik Kota}

Menurut Stephen Carr (1992) ruang publik dibagi menjadi beberapa tipe dan karakter sebagai berikut :

a. Taman Umum (Public Parks)

Berupa Lapangan / taman di pusat kota dengan skala pelayanan yang beragam sesuai dengan fungsinya. Tipe ini ada tiga macam yaitu :

- Taman Nasional (National Parks)

- Taman Pusat Kota (Downtown Parks)

- Taman Lingkungan (Neighborhood Parks)

- Taman Kecil (Mini Parks) 
b. Ruang Komunitas

Ruang komunitas ini berupa taman masyarakat (Community Garden).

c. Jalan Hijau Dan Jalan Taman

Merupakan jalan pedestrian yang menghubungkan antara tempat rekreasi dan ruang terbuka, yang dipenuhi dengan taman dan penghijauan.

Menurut Frey. H (1999) kriteria yang dapat mendorong kesinambungan bentuk dan struktur kota diperbandingkan antara kebutuhan dasar manusia menurut hirarki Maslow dan tuntutan kebutuhan fasilitas umum kota.

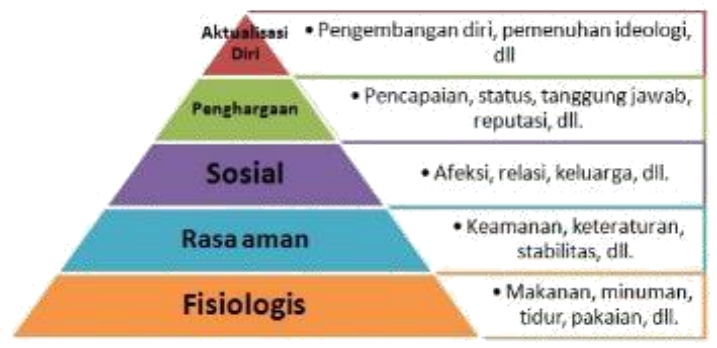

Gambar 6. Hirarki kebutuhan dasar manusia dan pengadaan fasilitas kota Sumber: Ruang publik dalam perancangan kota, 2010

\section{"TEMPAT KETIGA"}

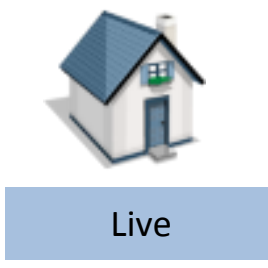

Privacy
Family
Food
Sleep
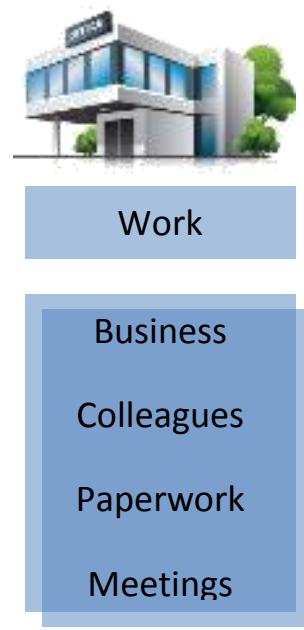

Gambar 7. $1^{\text {st }}, 2^{\text {nd }}, 3^{\text {rd }}$

Sumber: Penulis, 2019

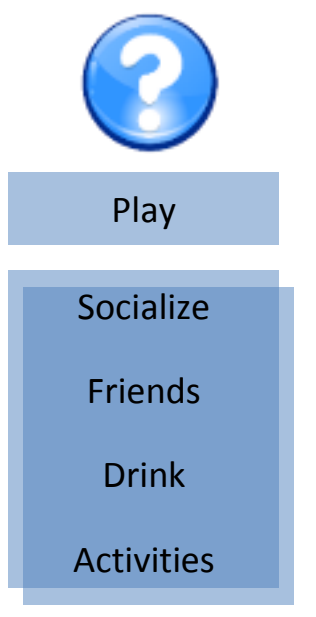

Secara sederhana, Oldenburg menyatakan bahwa "tempat ketiga" adalah inti dari suatu kegiatan sosial yang imformal dalam suatu tempat berkumpul publik yang imformal. Penggunaan kata "tempat ketiga" ini berasal dari pemikiran bahwa "tempat pertama" adalah rumah tempat kita tinggal dan "tempat kedua" adalah tempat kita bekerja. Jika kita melihat kehidupan di dalam rumah, hal yang biasa terjadi adalah adanya suatu keluarga inti yang terisolasi atau malah tinggal sendirian sedangkan tempat bekerja merupakan suatu hal yang identik dengan suatu yang terkurung dimana kita berhubungan dengan dunia luar melalui telepon dan internet. Kehidupan tanpa komunitas yang hanya terdiri dari " tempat pertama" dan "tempat kedua" akhirnya menciptakan suatu gaya hidup yang membosankan dan rutinitas ( dari rumah - tempat kerja - rumah, dan seterusnya ).

Yang ingin disampaikan dari hal ini adalah bahwa dalam pemenuhan kebutuhan manusia, manusia harus menemukan keseimbangan diantara 3 bidang pengalaman yaitu tempat tinggal, 
tempat kerja, dan tempat sosial. Ada beberapa factor yang membentuk "tempat ketiga" itu sendiri :

a. Public

Semua orang dapat hadi dalam "tempat ketiga". Tempat ini menyatukan orang-orang dari berbagai kalangan / latar belakang yang akhirnya membentuk suatu keberagaman

b. Space

Setiap tempat berkumpul memilikisuatu setting khusus dan unik, biasanya diselenggarai oleh individu atau organisasi.

Contoh : taman kota diselenggara oleh pemerintah setempat

c. For

Tujuan penyelenggara membuat "third place", ruang seperti apa yang diinginkan penyelenggara? dan bagaimana tanggapan dan respon pengunjung terhadap ruang tersebut?

d. Informal

Ketiadaan suasana formal. Menunjukan suatu suasana yang netral. Di "tempat ketiga" segala jabatan atau kedudukan yang di pakai sebelumnya seakan-akan pudar menyatu dengan kenetralan tempat tersebut.

e. Social

Konsep "tempat ketiga" memusatkan perhatiannya terhadap interaksi yang terjadi di antara manusia

"Tempat ketiga" tidak jarang menjadi tempat "pelarian" bagi orang yang sudah penat terhadap keadaan formalitas yang mereka lakukan setiap harinya dimana pekerjaan kantor yang menumpuk, persaingan antar jabatan, tidak adanya kebebasan, terkontrol, hubungan keluarga yang kurang baik, bisa menjadi alasan orang untuk pergi ke "tempat ketiga" dimana suatu tempat yang informal yang dapat mereka nikmati dan sukai. "tempat ketiga" dimana manusia dapat mengekspresikan dirinya secara bebas tanpa menutupi keadaan / berpura-pura, berkumpul bersama tanpa adanya perbedaan derajat, tidak terikat oleh aturan-aturan yang mereka lalui dimana mereka tinggal / bekerja. Manusia dapat menikmati hidupnya jika mereka dapat hidup dan bekerja dengan orang yang membuat mereka nyaman. Menurut Oldenburg, kualitas inti dari suatu "tempat ketiga" / ruang publik meliputi :

a. Neutral Ground

Adanya sifat netral dalam ruang publik dimana manusia dapat datang dan pergi sesuai keiinginan mereka

b. A Leveler Place

Tidak mementingkan status / derajat manusia, menghilangkan latar belakang / tingkatan baik sosial maupun ekonomi, terbuka bagi siapapun tanpa ada kriteria.

c. Conversation is The Main Activity

Percakapan = terjadinya interaksi / hubungan sosial diantara pengunjung merupakan aktivitas utama yang seharusnya terjadi.

Accessibility and Accomodation

Dapat diakses secara mudah tanpa adanya keanggotaan dan memenuhi kebutuhan pengunjungnya untuk bersosialisasi.

d. The Regulars

Merupakan orang - orang / pengunjung yang sering datang secara rutin ke sebuah tempat. Pengunjung regular awalnya merupakan pendatang, lalu terpengaruh oleh pengunjung regular yang telah ada sebelumnya. Pendatang inilah yang memiliki peran penting bagi Third Place itu sendiri. 
e. A Low Profile

Mengesampingkan latar belakang dan tingkatan sosial pengunjung dan menerima pengunjung apa adanya. Third Place tidak dianjurkan memiliki karakter yang megah dan berlebihan agar memberikan rasa aman dan nyaman.

f. A Home Away from Home

Perasaan homey, dimana pengunjung dapat merasakan kedekatan dengan rumah mereka. Perasaan itulah yang mengikat mereka untuk menghabiskan waktunya pada ruang tersebut.

g. The Mood is Playful

Memiliki karakteristik ruang, sehingga manusia merasa "playful mood". Suasana yang menyenangkan memberi rasa santai dan nyaman sehingga dapat mengalahkan rasa ketegangan, kesepian, dan kegelisahan. Perasaan seperti inilah yang membedakan antara Third Places dengan tempat lain dimana dapat menciptakan candaan dan percakapan yang menyenangkan

Manusia dan ruang merupakan dua elemen yang saling mempengaruhi dan berkaitan. Ruang membutuhkan manusia untuk membentuknya, sementara manusia memerlukan ruang sebagai tempat bergerak dan beraktifitas. Hal ini dapat dilihat melalui perilaku manusia ketika mengisi sebuah ruang, cenderung tidak mendistribusikan dirinya secara merata didalamnya, tetapi mereka akan mendatangi titik yang telah terisi oleh sekumpulan orang lainnya (Whyte, 1980). Dari adanya interaksi manusia secara berkelompok tersebut, akan terbentuk ruang dalam ruang pada dimensi yang lebih kecil dan intim.

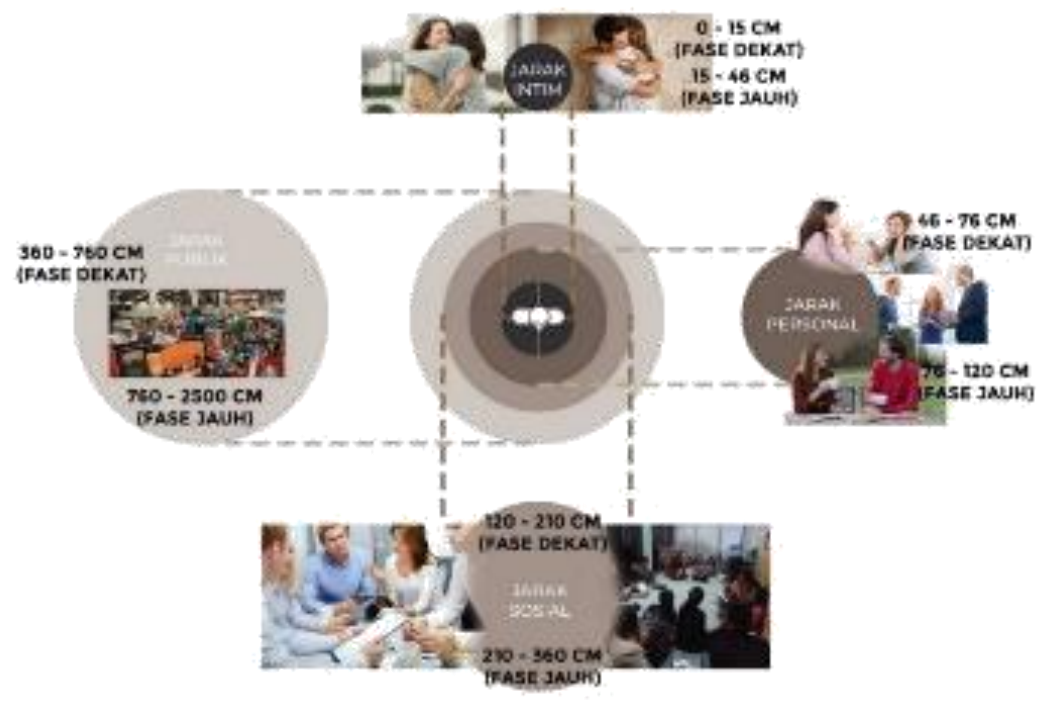

Gambar 8. Diagram zona jarak pada interaksi manusia Sumber: Penulis, 2019

\section{METODE}

\section{KONSEP TATA RUANG}

Tipologi bangunan bersifat rekreasi dan edukatif dengan konteks modern dan berteknologi canggih. Berdasarkan hal tersebut maka dibentuklah konsep tata ruang berikut :

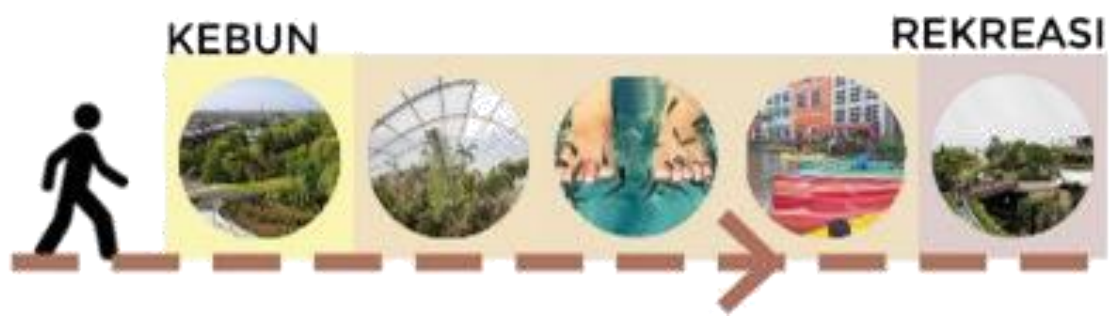

Gambar 9. Skema Tata Ruang

Sumber: Analisis Penulis, 2019 
Bangunan ini dikelilingi oleh rekreasi tanaman penyerap polusi udara, pada tengah area / hall terdapat area Amphiteater dimana pengunjung dapat melepaskan rasa penat dengan cara merangkai bunga Bersama-sama pengunjung lainnya. Memasuki abad ke-21 dimana kebutuhan pangan sangat dibutuhkan sehingga memberikan peluang besar bagi petani di dunia agricultural sehingga terdapat area Penanaman Hidroponik dimana juga pengunjung dapat memetik sayursayuran dan buah-buahan secara langsung serta terdapat RealFood District yang merupakan program yang menyajikan makanan-makanan dengan real-food system, dimana bahan baku dari bahan organic yang diambil langsung dari hasil panen vertical farming.

\section{MORPHOSIS ENVIRONMENT PADA KONSEP RUANG}

a. Privat Place in Public Space

Terjadi kontras antara eksterior dan interior bangunan dimana kebisingan dan polusi berlawanan dengan ketenangan dan kenyamanan. "Ramai tapi hening" dan "Ramai tapi privasi / terjaga". Menyediakan tempat yang nyaman, tenang, sejuk, dan homey bagi pengunjung.

b. Interaction with Fish and Human

Menyediakan tempat dimana pengunjung dapat berinteraksi satu sama lain dalam zona jarak interaksi manusia. Adanya RealFood District yang berfungsi sebagai restaurant yang menawarkan bahan baku makanan organik yang diambil langsung dari hasil panen hidroponik dan aquaponic. Terdapat kolam ikan yang dapat memakan sel-sel kulit mati pada kaki. Jenis ikan tersebut adalah ikan Garrarufa Osteochilus Vittatus dan ikan koi . Ikan ini dapat hidup di kolam dengan suhu $30^{\circ}-34^{\circ} \mathrm{C}$. Selain itu juga terdapat Kebun Koleksi dimana sebagai wadah untuk melestarikan berbagai koleksi jenis tanaman / tumbuhan dan meningkatkan kesadaran masyarakat untuk perduli dengan tanaman.

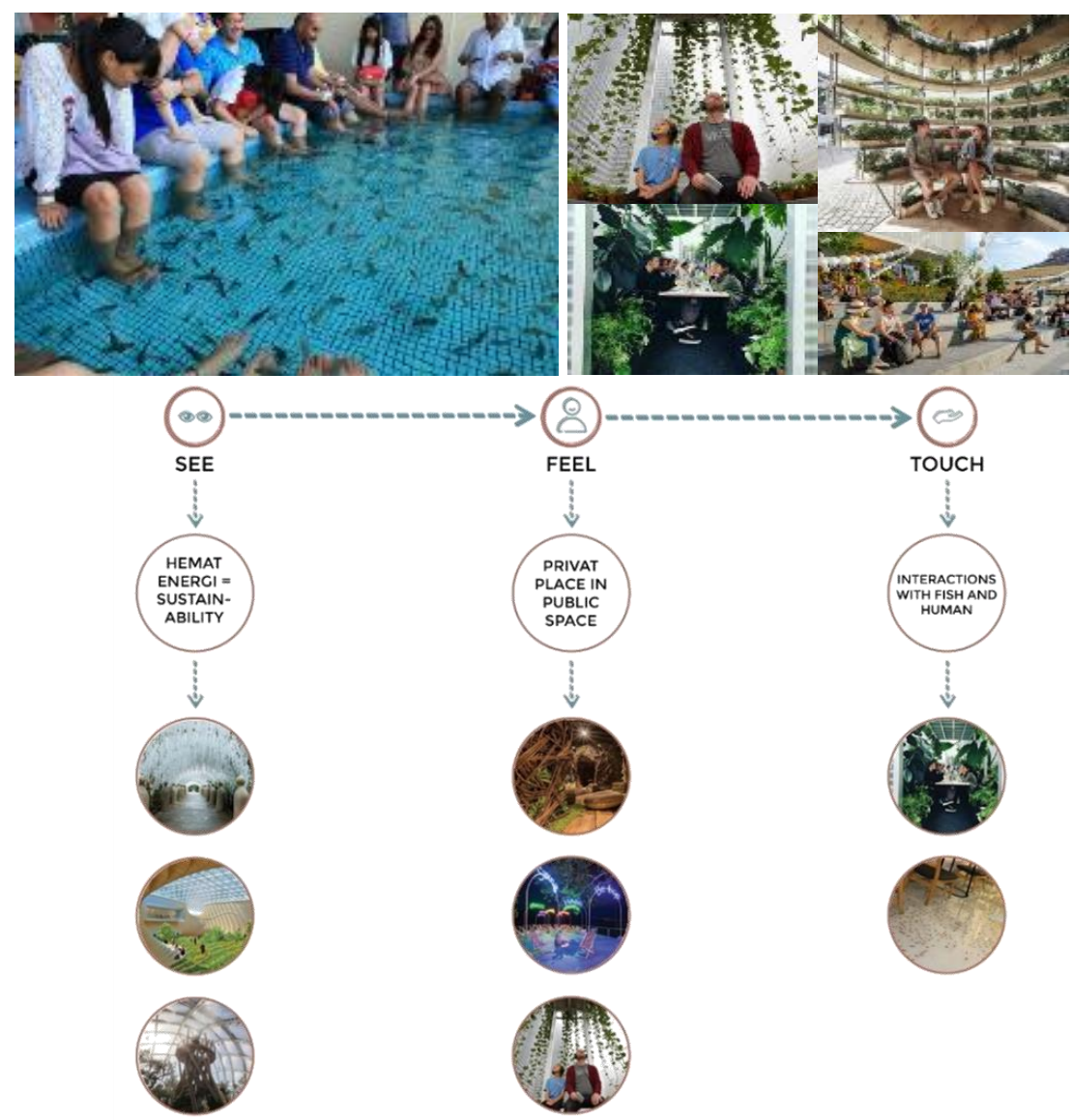

Gambar 10. Morphosis Environment Pada Konsep Ruang Sumber: Analisis Penulis, 2019 


\section{Pengumpulan Data / Studi Lapangan}

Metode ini digunakan untuk membantu peneliti menganalisis tapak terpilih. Pengamatan pertama diawali pada tanggal 22 Juli 2019 pukul 17.00 WIB. Kemudian survei lapangan dilakukan kembali Pada tanggal 10 Agustus 2019 pukul 16.00 WIB, 13 Agustus 2019 pukul 14.00 WIB, dan 15 Agustus 2019 pukul 16.00 WIB dilakukan pengamatan fisik dan kegiatan (observasi ) di sekitar tapak terpilih ( ada 3 jenis pilihan tapak yang berbeda ). Survei lapangan dilakukan kembali pada tanggal 23 Agustus 2019 pukul 16.00 - 19.00 WIB dan 24 Agustus 2019 pukul 13.00 WIB dilakukan pengumpulan data yang diperoleh langsung dari sumber asli ( tidak melalui media perantara ) yaitu dengan penyusunan kuisioner dengan pengambilan sampling sebanyak 30 orang dan menghitung akumulasi hasil dari perhitungan kuisioner yang telah dibuat dan disusun untuk mengetahui respon dari masyarakat Kawasan Kelurahan Paseban terhadap kebutuhan akan lahan terbuka hijau untuk mengurangi polusi udara yang tinggi. Dengan parameter membawa isu yang diangkat yaitu "Penurunan Degradasi Kualitas Lingkungan Akibat Pencemaran Udara".

Survei dilakukan di 3 jenis tempat yang berbeda yaitu Pasar Proyek Senen (segitiga Senen), perempatan Jalan Salemba Raya dan Pramuka Raya ( deket flyover Pramuka ), Jalan Pemuda ( samping UNJ \& dekat Green Pramuka Apartment ). Hasil kesimpulan dari survei lapangan 15 Agustus 2019 adalah tapak dekat dengan Universitas Indonesia di Salemba, RSCM ( Rumah Sakit Cipto Mangunkusumo ), Apartment Capitol Park, SMAN 68, Rumah Sakit Carolus, Gunadarma University, Apartment Menteng Square, dan lainnya. Keadaan existing tapak merupakan tanah kosong milik PT. Solid Gold Abadi sebesar $\pm 26.000 \mathrm{~m}^{2}$. Memiliki mobilitas kendaraan yang mudah dicapai dan pergerakan pejalan kaki pada pedestrian kurang nyaman di sekitar tapak. Terdapat fasilitas transportasi umum yang memadai. Disekitar tapak pada jam padat terdapat beberapa titik - titik kemacetan. Hasil kesimpulan dari survey lapangan 23 Agustus 2019 adalah sedikitnya pejalan kaki yang melintas dikarenakan pedestrian yang kurang nyaman, kendaraan seperti mobil dan motor banyak yang melewati tapak. Terdapat jalan flyover dan underground di sekitar tapak yang berfungsi untuk mengurangi kemacetan pada jam padat.

\section{DISKUSI DAN HASIL}

Proyek ini dinamakan sebagai Taman Vertikal di Matraman / Matraman Vertical Park dengan konsep dasar Third Place yang menyediakan ruang bagi manusia untuk bersosialisasi dan memberikan penghiburan yang berkontribusi positif terhadap lingkungan perkotaan, serta konsep morphosis environment pada tata ruang yang menghadirkan interaction space bagi pengunjung, Sustainability Targets yaitu menggunakan material yang hemat energi, menyediakan tempat yang nyaman dan tenang bagi pengunjung lewat panca indra, serta meningkatkan kualitas lingkungan dari pencemaran udara dengan adanya taman yang berfungsi sebagai jantung kota sehingga polusi udara berkurang dan kesehatan manusia dapat meningkat. Serta dapat memperkaya pengetahuan mengenai berbagai jenis tumbuhan, dapat menghilangkan rasa jenuh, kekosongan, hampa, dan penat dalam batin manusia. 


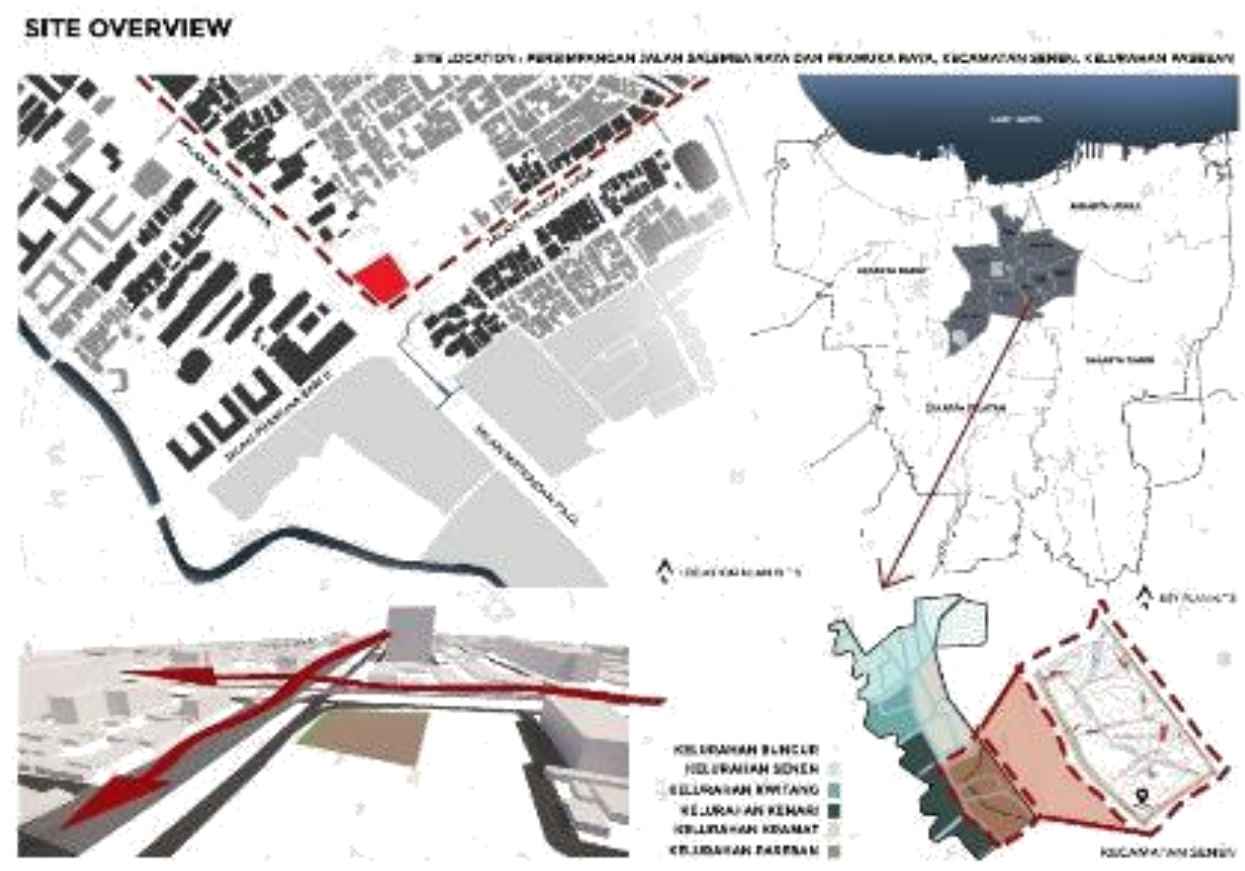

Gambar 11. Site Overview

Sumber: Analisis Penulis, 2019
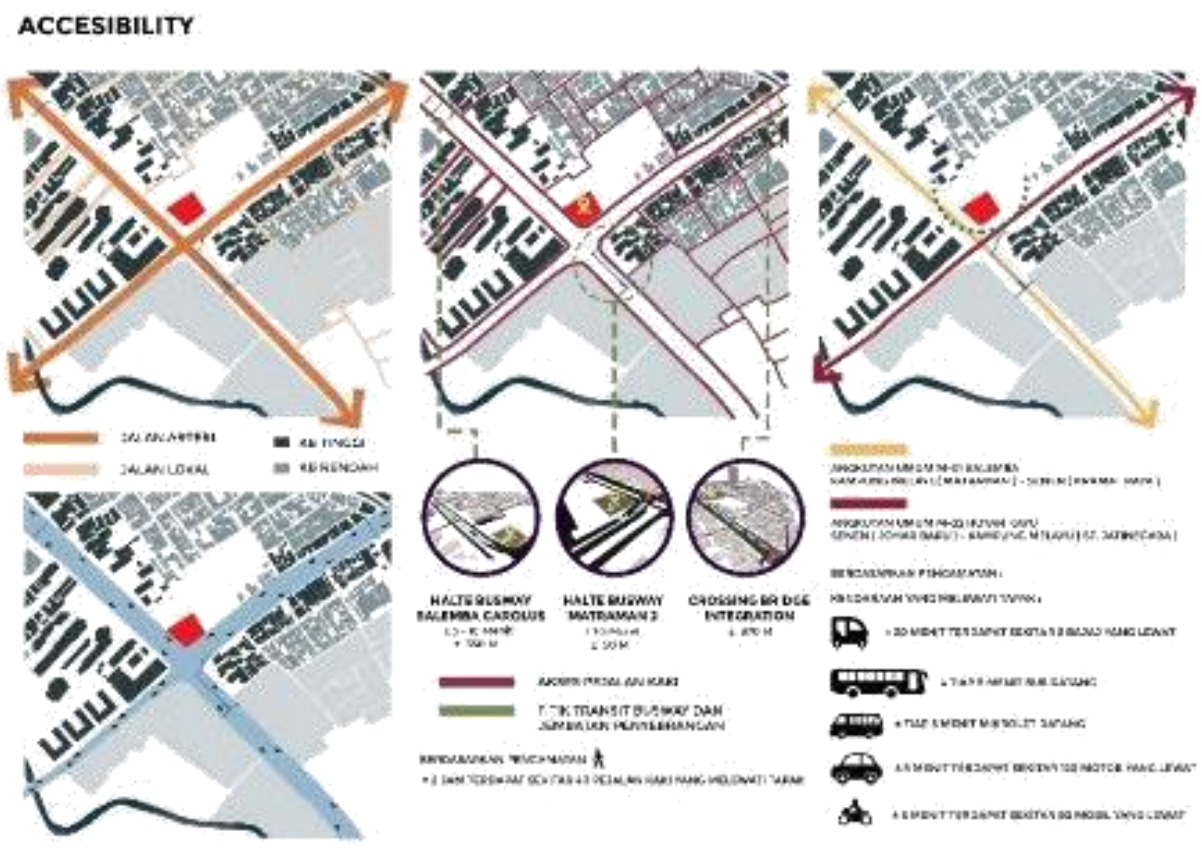

Gambar 12. Aksebilitas di sekitar tapak

Sumber: Penulis, 2019

Berdasarkan gambar diatas, proyek ini berada di perbatasan antara Jakarta Pusat dan Jakarta Timur yang terletak di persimpangan Jl. Salemba Raya dan Pramuka Raya. Pergerakan mobilitas pedestrian di sekitar tapak sepi dikarenakan jalur pedestrian yang kurang nyaman untuk dilewati. Site memiliki peraturan pemerintah yaitu memiliki luas tapak $3.026,17 \mathrm{~m}^{2}$ dengan besaran proyek sekitar $\pm 5.000 \mathrm{~m}^{2}$. memiliki tinggi bangunan maksimal 8 lantai dengan peruntukan perkantoran, perdagangan, dan jasa. Daerah hijau sekitar 1.083,40 $\mathrm{m}^{2}(\mathrm{KDH} 30 \%$ ), luasan dasar bangunan maksimal sebesar 1.664,40 $\mathrm{m}^{2}$ ( KDB $55 \%$ ), dan luasan basement maksimal sekitar 1.664,40 $\mathrm{m}^{2}$ ( KTB $55 \%$ ). GSB pada bangunan ini sebesar $4 \mathrm{~m}$. 


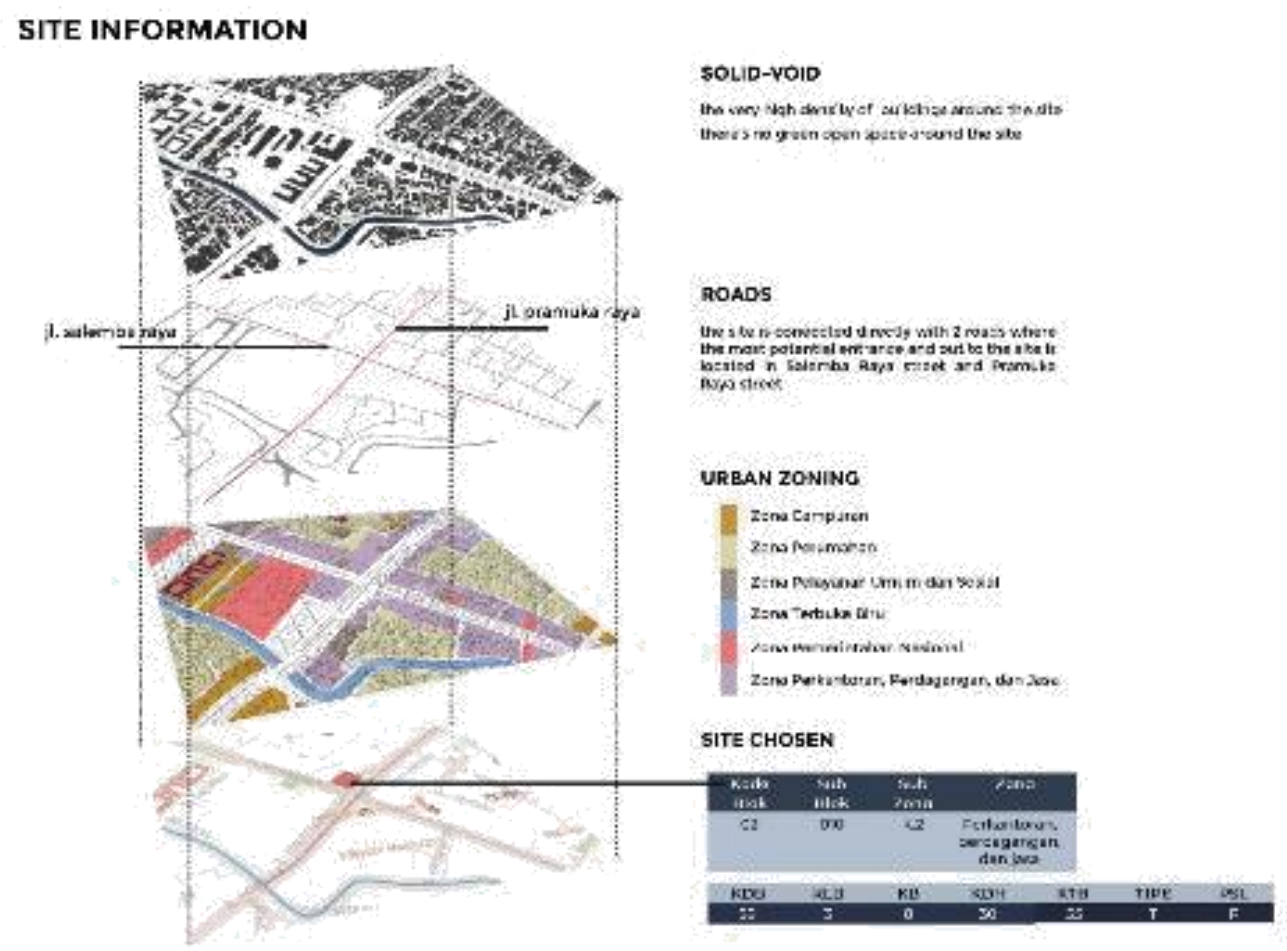

Gambar 13 Pemetaan fungsi bangunan di sekitar Tapak Sumber: Penulis, 2019

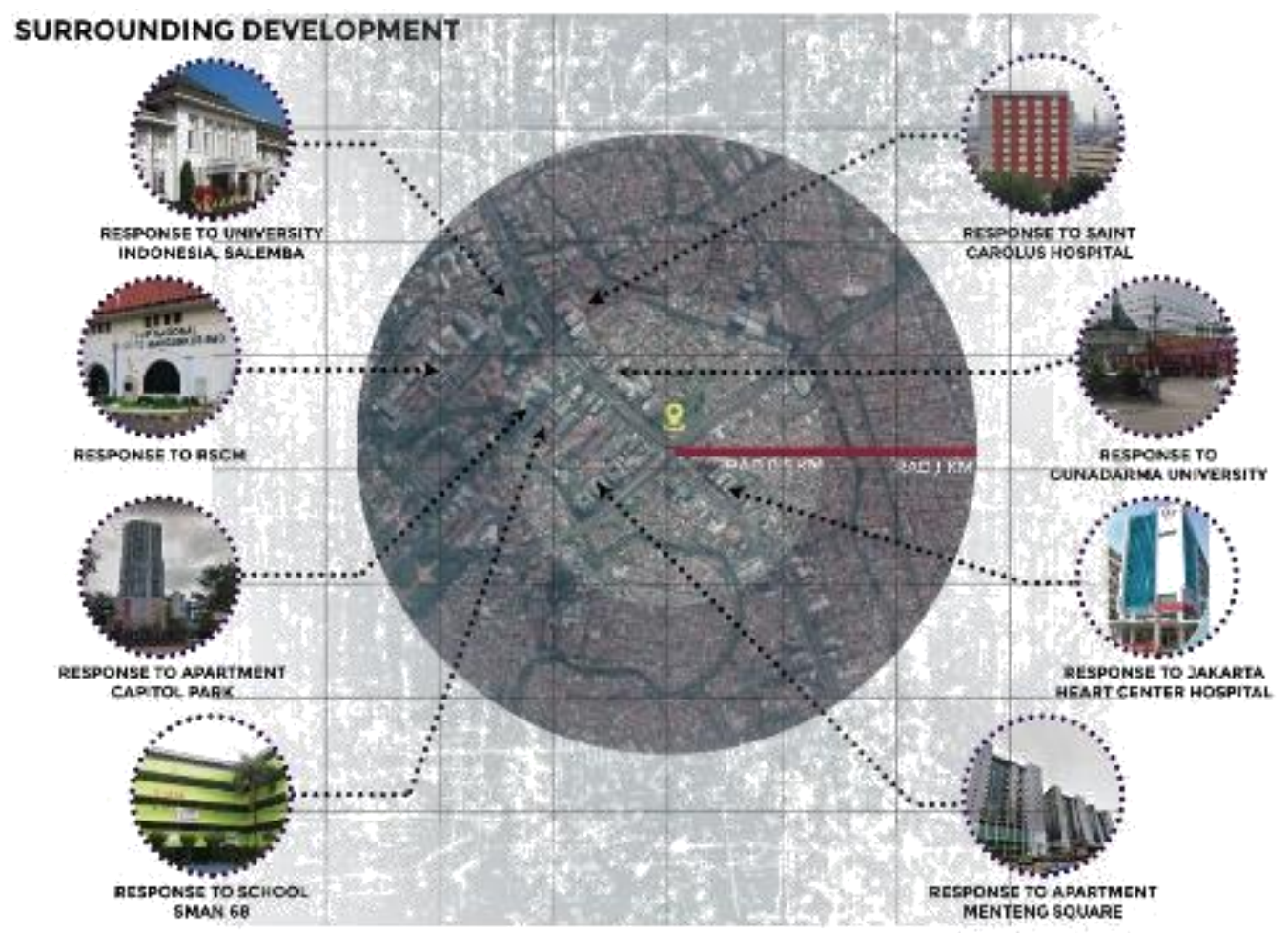

Gambar 14 Surrounding Development

Sumber: Penulis, 2019 


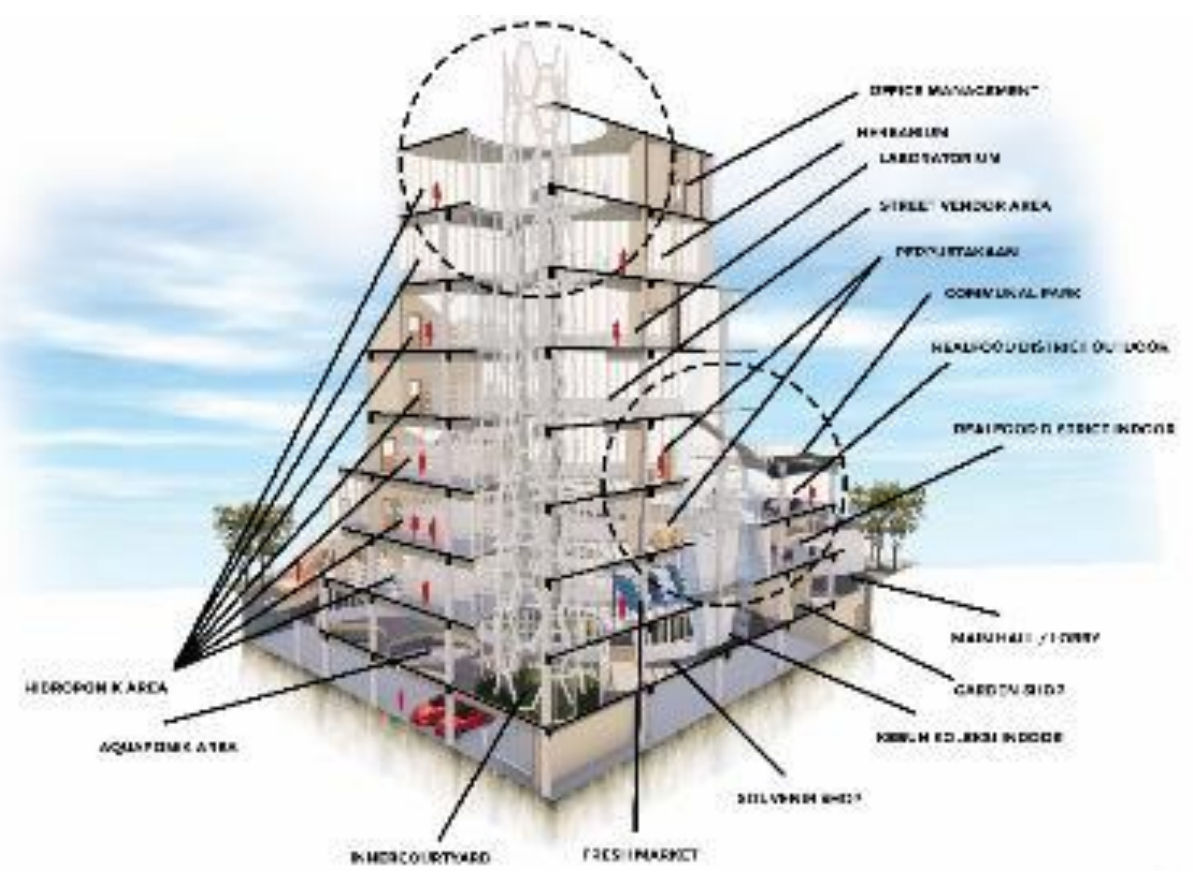

Gambar 15. Diagram Peletakan Program pada bangunan

Sumber: Penulis, 2019

Berdasarkan gambar diatas, program ini terdiri dari 6 program yang dibagi menjadi 2 bagian yaitu 3 program utama dan 3 program pendukung. Program utama bangunan ini yaitu Vertical Farming ( Hidroponik dan Aquaponik ), Growing Field Area (Gardening ), RealFood District ( bahan baku organik ) \& Fresh Market. Program pendukung seperti communal park, ruang baca, dan laboratorium. Terdapat juga fasilitas pelengkap lainnya yang dibutuhkan seperti Lobby, Emergency area, dan Service area sehingga fasilitas - fasilitas tersebut diletakan berdekatan didalam bangunan ini yang menjadi suatu core utama di dalam bangunan.

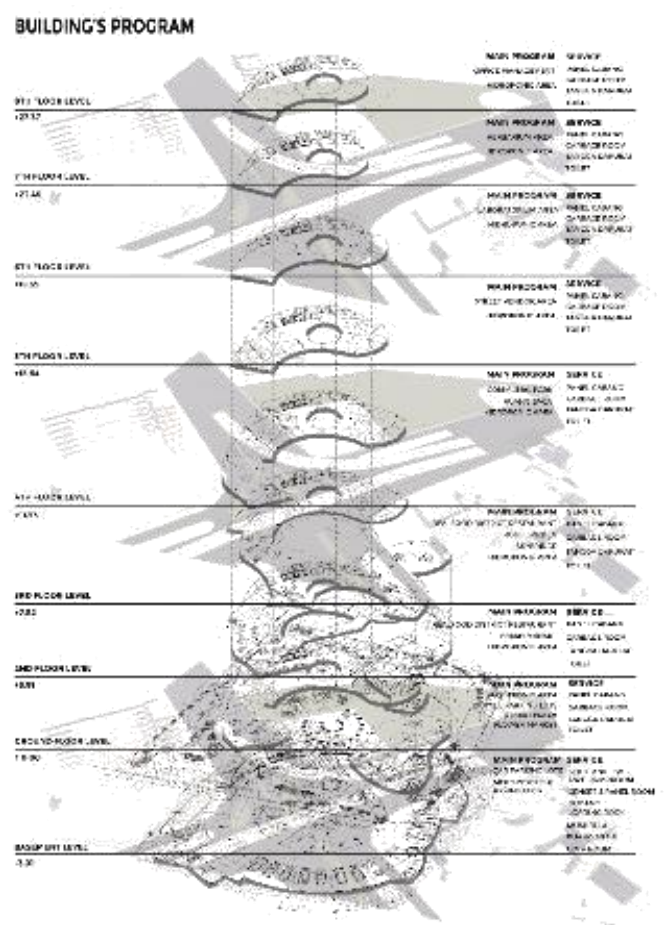

Gambar 16 Building's Program

Sumber: Penulis, 2019 
Berikut gambar disamping adalah diagram exploded denah pada proyek ini. Pada gambar dibawah ini akan dijelaskan mengenai pengelompokan ruang tiap lantai sesuai dengan fungsinya. Bangunan ini memiliki beberapa design ideas yaitu Vertical Farming, Pedestrian Oriented, dan RealFood District Area. Mementingkan pedestrian sebagai pengguna utama didalam bangunan ini sehingga memisahkan sirkulasi kendaraan dengan sirkulasi pedestrian serta adanya ramp untuk pengguna disabilitas.

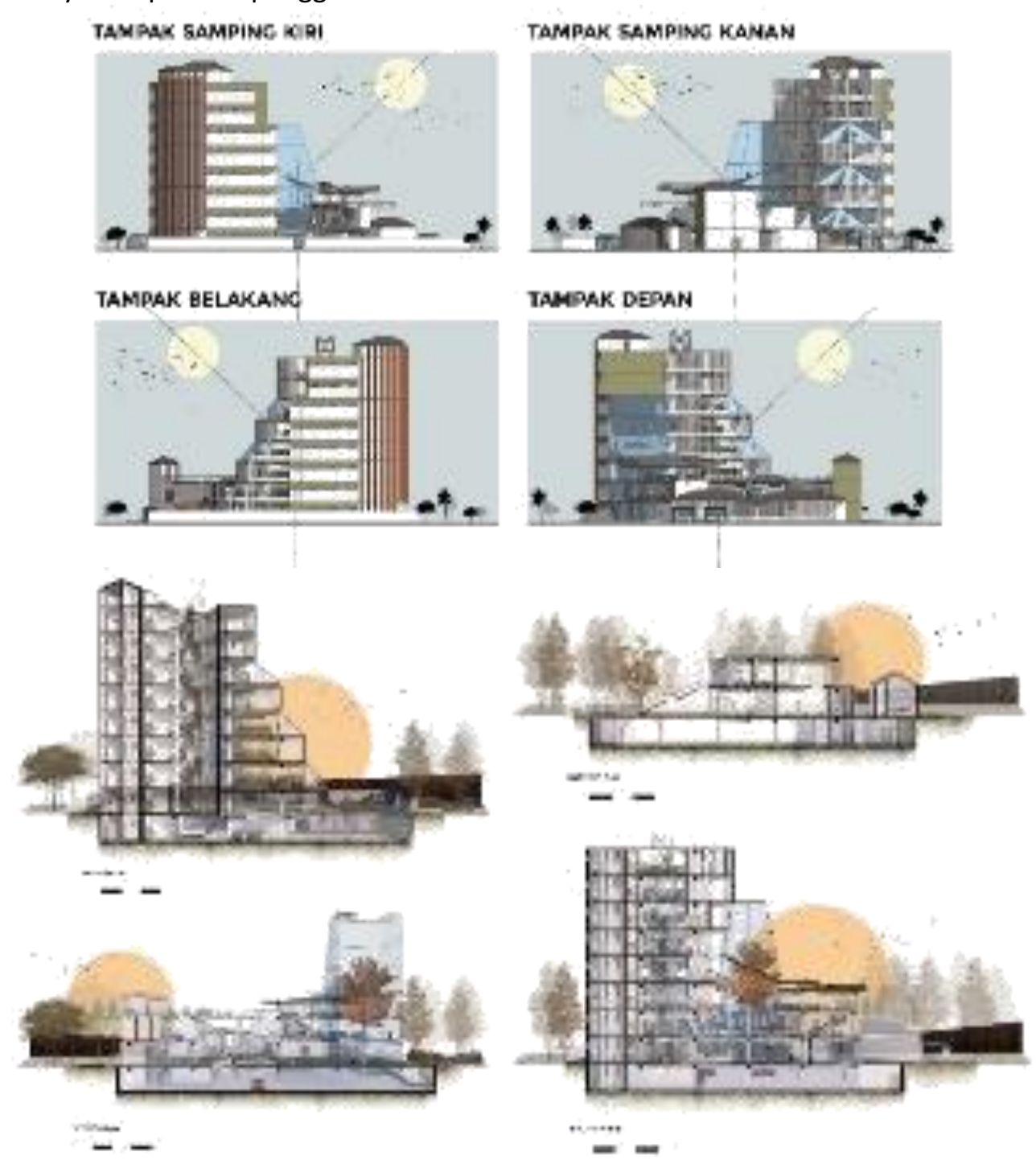

Gambar 17 Fasad Bangunan dan Potongan Perspektif Bangunan Sumber: Penulis, 2019

Berdasarkan gambar diatas adalah gambar fasad bangunan. Bisa dilihat pada fasad bahwa bangunan ini mengangkat kesan back to nature dimana konsep arsitektur yang menyatu dengan alam dengan mengaplikasikan taman vertikal dan roof garden pada bangunan serta pemanfaatan material yang ramah lingkungan. Dapat dilihat juga pembagian ruang indoor, semi outdoor, dan outdoor pada fasad. Penggunaan konsep steven holl pada ruang kaca dimana cahaya dapat masuk kedalam bangunan. Penggunaan kisi - kisi pada tampak bangunan agar udara dapat bebas masuk ke dalam ruangan sehingga terjadi cross ventilation.

Pada gambar potongan perspektif diatas, dapat dilihat bahwa bangunan ini memiliki 2 skylight sehingga cahaya matahari langsung masuk ke dalam bangunan. Memiliki inner courtyard di tengah bangunan serta amphiteater yang digunakan sebagai tempat untuk merangkai bunga. Memisahkan sirkulasi pedestrian kendaraan dan pedestrian agar tidak crossing. Memiliki 2 gubahan massa yang dihubungkan dengan jembatan sebagai penghubung ( 
skybridge ). Memiliki void pada massa utama bangunan sehingga memberikan kesan adanya hubungan ruang tiap lantai.

Gambar 19 adalah gambaran suasana bangunan melalui perspektif eksterior maupun interior. Pada bangunan ini memanfaatkan suasana semi-outdoor dengan kesan natural sehingga pengunjung dapat menikmati quality time bersama orang terdekat serta ketenangan dan kenyamanan di dalam bangunan.

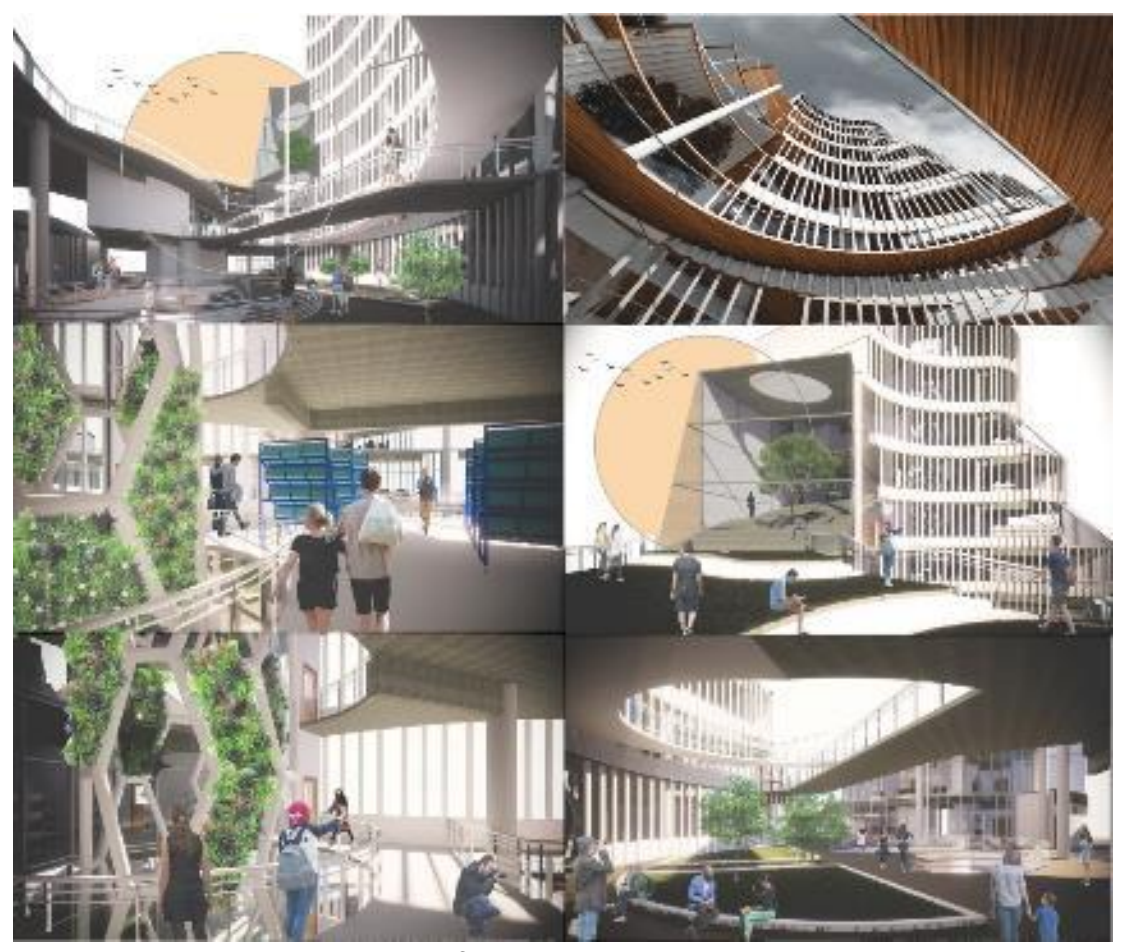

Gambar 18. Perspektif Eksterior dan Interior Bangunan Sumber: Penulis, 2019

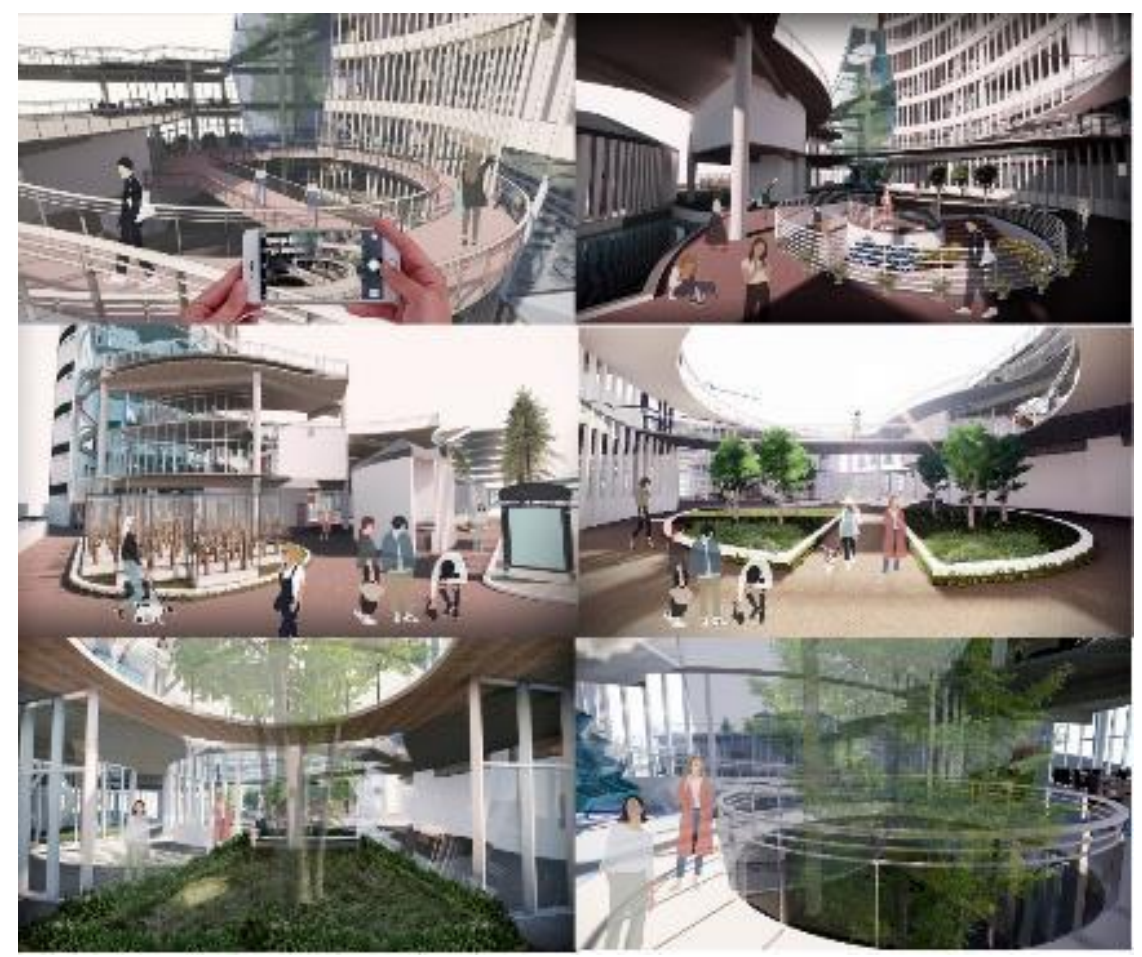

Gambar 19. Perspektif Eksterior dan Interior Bangunan Sumber: Penulis, 2019 


\section{KESIMPULAN DAN SARAN \\ Kesimpulan}

Dari data dan program yang penulis buat, dapat disimpulkan bahwa setiap program memiliki karakter dengan ciri khas yang berbeda dari masing-masing fungsi. Perbedaan karakter inilah yang nantinya saling melengkapi antara program yang satu dengan program lainnya sehingga terbentuklah suatu kesatuan dan keseimbangan desain. Selain itu Penyelesaian masalah maraknya polusi udara di Jakarta dapat dilakukan dengan dibentuknya ruang terbuka hijau agar masyarakat sadar dan peduli akan tanaman khususnya anak millennial yang mengalami chronic stress dapat melepaskan rasa jenuh yang dihadapi setiap harinya. Keberadaan proyek ini di masyarakat dapat memberikan sudut pandang yang berbeda dengan menjadikan proyek ini sebagai tempat interaksi manusia dengan binatang maupun manusia dengan sesama manusia. Perancangan bangunan menggunakan konsep sustainability targets dimana menggunakan penghematan energi, recycling water, dan roof garden.

\section{Saran}

Tujuan penyusunan jurnal ini adalah untuk memberikan sebuah paparan mengenai Vertical Park sehingga dapat berguna bagi para pembaca, penyusunan jurnal ini disusun dengan sebaikbaiknya, namun masih terdapat kekurangan didalam penyusunan jurnal ini, oleh karena itu saran dan kritik yang sifatnya membangun dari semua pihak sangat diharapkan. Mohon maaf apabila ada kesalahan kata dalam penyusunan jurnal ini.

\section{REFERENSI}

Carmona, M. and team. (2003). Public Places Urban Spaces. Oxford: Architectural Press. Dear, M. and Walch, J. (1989). How Territory Shapes Social Life. Boston: Unwin Hyman. Gans, H.J. People and planning: Essays on Urban Problems and Solutions. London: Penguin. Lawson, B. (2001). The Languange of Space. London: Architectural Press.

Lefebvre, H. (1991). The Production of Space. Cambridge, Massachusetts: Basil Blackwell, Inc. Lynch, K. (1972a). Openness of Open Space, in Banerjee, T. and Southworth, M. (1990). City Sense and City Design: Writings and Projects of Kevin Lynch. Cambridge: MIT Press hal. 396 -412 .

Oldenburg, R. (1997). Our Vanishing "Third Places" (Planning Commissioners Journal, \#25).

Oldenburg, R. (1999). The Great Good Place: Cafes, coffe shops, bookstores, bars, hair salons and the other hangouts at the heart of a community ( second edition ). New York: Marlowe \& Company.

Schneekloth, L.H. and Robert G.S. (1995). Placemaking: The art and practice of building communities, Canada: John Wiley and Sons, Inc.

Zevi, B. (1974). Architecture as Space: How to Look at Architecture. New York: Horizon Press.

Zucker, P.( 1959). Town and Square: From the Agora to Village Green. New York: Columbia University Press.

Menurut Anies, Ini Penyumbang Terbesar Polusi Udara Jakarta..., diunduh 26 Juni 2019, $<$ https://megapolitan.kompas.com/read/2019/06/26/17053511/menurut-anies-inipenyumbang-terbesar-polusi-udara-jakarta>

Jakarta Darurat Polusi Udara, Indeks Kualitas Udara Menyentuh Angka 191, diunduh 30 Juli 2018, <https://www.tribunnews.com/nasional/2018/07/30/iakarta-darurat-polusi-udaraindeks-kualitas-udara-menyentuh-angka-191>

Perencanaan dan perancangan Botanical Garden Visitor Center di Sleman, diunduh 30 Juli 2019, <http://e-journal.uajy.ac.id/7111/7/6TA13562.pdf>

Jakarta nomor 18 kota paling stress di dunia, diunduh 30 Juli 2018, $<$ https://properti.kompas.com/read/2017/10/30/090000621/jakarta-nomor-18-kotapaling-stres-di-dunia?page=all> 
Kemampuan Berbagai Jenis Tanaman Menyerap Gas Pencemar Udara $\left(\mathrm{NO}_{2}\right)$, diunduh 2004 $<$ https://inis.iaea.org/collection/NCLCollectionStore/ Public/44/069/44069204.pdf> $<$ http://repository.unpas.ac.id/13365/2/03\%20BAB\%201\%20Pasca\%20Sidang.pdf > $<$ https://www.mongabay.co.id/2019/03/09/laporan-ungkap-polusi-udara-jakarta-terburuk diasia-tenggara/> $<$ https://thesiscommons.org/5fdns/download/?format=pdf>

Penyalahgunaan Fungsi Ruang Publik Sebagai Sarana Penunjang Aktivitas Penghuni Hunian Vertikal Kota, diunduh Februari 2016 <https://ejurnal.itenas.ac.id/index.php/rekakarsa/article/viewFile/1390/1555> 
